\title{
Checklist of Macroalgae in Waisai Coast, Raja Ampat
}

\author{
Retno Suryandari ${ }^{1}$, Widodo \\ Departement of Biological Education, Faculty of Science and Technology, UIN Sunan Kalijaga, \\ Jl. Marsda Adisucipto No 1 Yogyakarta 55281, Indonesia. Tel. +62-274-540971, Fax. +62-274-519739
}

Author correspondency ${ }^{1}$ :

suryandari44@gmail.com

\begin{abstract}
Macroalgae are very abundant organisms in Indonesian coastal zone. They comprise $8.6 \%$ of the total marine organisms.The aim of the research was to identify macroalgae in Waisai Coast Raja Ampat. The results showed that 38 macroalgae were found in Waisai Coast Raja Ampat but only 29 species of macroalgae can be identified. Macroalgae found in Waisai Coast Raja Ampat are green algae, red algae and brown algae. Green algae found and identified are Caulerpa macra (Weber-van Bosse) Draisma \& Prud'homme, Caulerpa racemosa var. macrophysa (Sonder wx Kutzing) W.R.Taylor, Caulerpa sertularoides (S. Gmelin) Howe f. brevipes (J. Agardh Svedilus), Caulerpa cupressoides (Vahl) C. Agardh, Halimeda discoidea Decaisne, Halimeda Opuntia (Linnaeus) J.V. Lamoroux, Halimeda tuna (J. Ellis \& Solander) J.V. Lamoroux, Halimeda cylindraceae Decaisne, Halimeda macroloba Decaisne, Avrainvillea erecta (Berkeley) A. Gepp \& E.S. Gepp, Codium geppiorum O.C.Schmidt, Boergesenia forbesii (Hardvey) Feldmann, Valonia ventricosa J. Agardh, Dictyosphaeria cavernosa (Forsskål) Børgesen, Chaetomorpha spiralisOkamura, Anadyomene wrightii Harvey ex. J. E. Gray, Neomeris annulata Dickie. Red algae species found and successfully identified areAcanthophora spicifera (M. Vahl) B $\emptyset$ rgesen, Laurencia papilosa (C. Agardh) Greville, Gracilaria salicornia (C. Agardh) E.Y. Dawson, Amphiora fragilissima (Linnaeus) J.V. Lamoroux, Hypnea pannosa J. Agardh. Brown algae species found and identified are Hormophysa cuneiformis (J.F. Gmelin) P.C. Silva, Sargassum aquifolium (Turner) C. Agardh, Sargassum polycystum C. Agardh, Turbinaria ornata (Turner) J. Agardh, Padina australis Hauck, Canistrocarpus cervicornis (Kutzing) De Paula \& De Clerck Hydroclathrus clatratus (C. Agardh ) M. Howe. The only species found in Indonesia is Sargassum aquifolium.
\end{abstract}

Keywords: Macroalgae, Waisai Coast, Raja Ampat, Green Algae, Red Algae, Brown Algae

\section{Introduction}

Indonesia have more than 17,504 islands. Approximately three-quarters of Indonesian territory are ocean (5.8 million $\mathrm{km} 2)$ with $95.161 \mathrm{~km}$ coastline. Indonesia have the second longest coastline in the world (Lasabuda, 2013). Indonesia's marine wealth runs between the Indian Ocean to the Pacific Ocean with an area of coral reefs achieve $50.875 \mathrm{~km}^{2}$ or $18 \%$ of the world's coral reefs. Most of these reefs are located in the eastern part of Indonesia on the Coral Triangle region. One of the center of coral reef biodiversity are in Raja Ampat (Solihin, Batungbacal, \& Nasution, 2013).

Raja Ampat Islands is an area located in the western part of Papua. The islands are known as one of the Marine World Heritage Site because of its marine biodiversity. In 2002, The Nature Conservation (TNC) and the Research Center for Oceanography LIPI reported data that the marine ecosystem consist of 537 species of corals ( $75 \%$ of coral species in the world), and 828 species of fish (Setiawan, 2011). In Raja Ampat, coral reef ecosystems exposed in the shallow areas in most of islands.Coral reefs are usually covered with abundance of seaweed that is not only diverse if compared with other living beings but also more complex in morphology and ecological role in coral reef ecosystems (Mambrisaw, Wurlianty, Liuw, \& Hamel, 2006).

Waisai Coast is located around the port of Raja Ampat, South Waigeo district, Raja Ampat, West
Papua.This area can be reached by sea from Sorong city and overland from Waisai city.Waisai Coastzonation started from the mainland that made up of mangrove forest dominated by Rhizophora Genus, then towards the shallow water, seagrass species dominate byEnhalus sp. with various sizes up to $40 \mathrm{~cm}$. Among the seagrasses are found living macroalgae associated with seagrass and coral. This coast has a mixed substrate consist of dead corals and mud sand.

According to Dahuri (1998) in Suparmi \& Sahri (2009) seaweed is a biological resource that is very abundant in Indonesian ocean which is comprised of $8.6 \%$ of the total marine organisms. The seaweed habitat in Indonesia reached 1.2 hectares, one of the largest in the world (Wawa, 2005) in Suparmi \& Sahri (2009). Based on the report by Vamn Bosse, Indonesia has 555 of 8642 world seaweed species (Suparmi \& Sahri, 2009). Mambrisaw et al (2006) stated that in the area of Raja Ampat Misool particularly in the South East, South and Ayau Waigeo, seaweed has been cultivated and are the main commodity in the region. However, checklist of macroalgae in Raja Ampat have not been done.

Seaweeds (macroalgae) are organisms like plants that live in marine ecosystems which is a primary producer because it has the ability to photosynthesize (autotrof). Macroalgae are classified into three main groups, namely green algae (Chlorophyta), brown algae (Phaeophyta) and red algae (Rhodophyta) (Dhalgarkar \& Kavlekar, 2004). In addition to a taxonomic grouping, macroalgae can be distinguished by the character of the 
organism and its ecological characteristics. Based on this category of macroalgae are grouped into three main categories: 1.Turf algae, 2. fleshy algae (fleshy and calcified) 3. Crustose corraline algae (Mambrisaw, Wurlianty, Liuw, \& Hamel, 2006).

This research aims to determine the types of macroalgae found in Waisai Coast of Raja Ampat.

\section{Materials and Methods}

The research was conducted on 4-5 April 2016 in Waisai Coast, South Waigeo district, Raja Ampat.

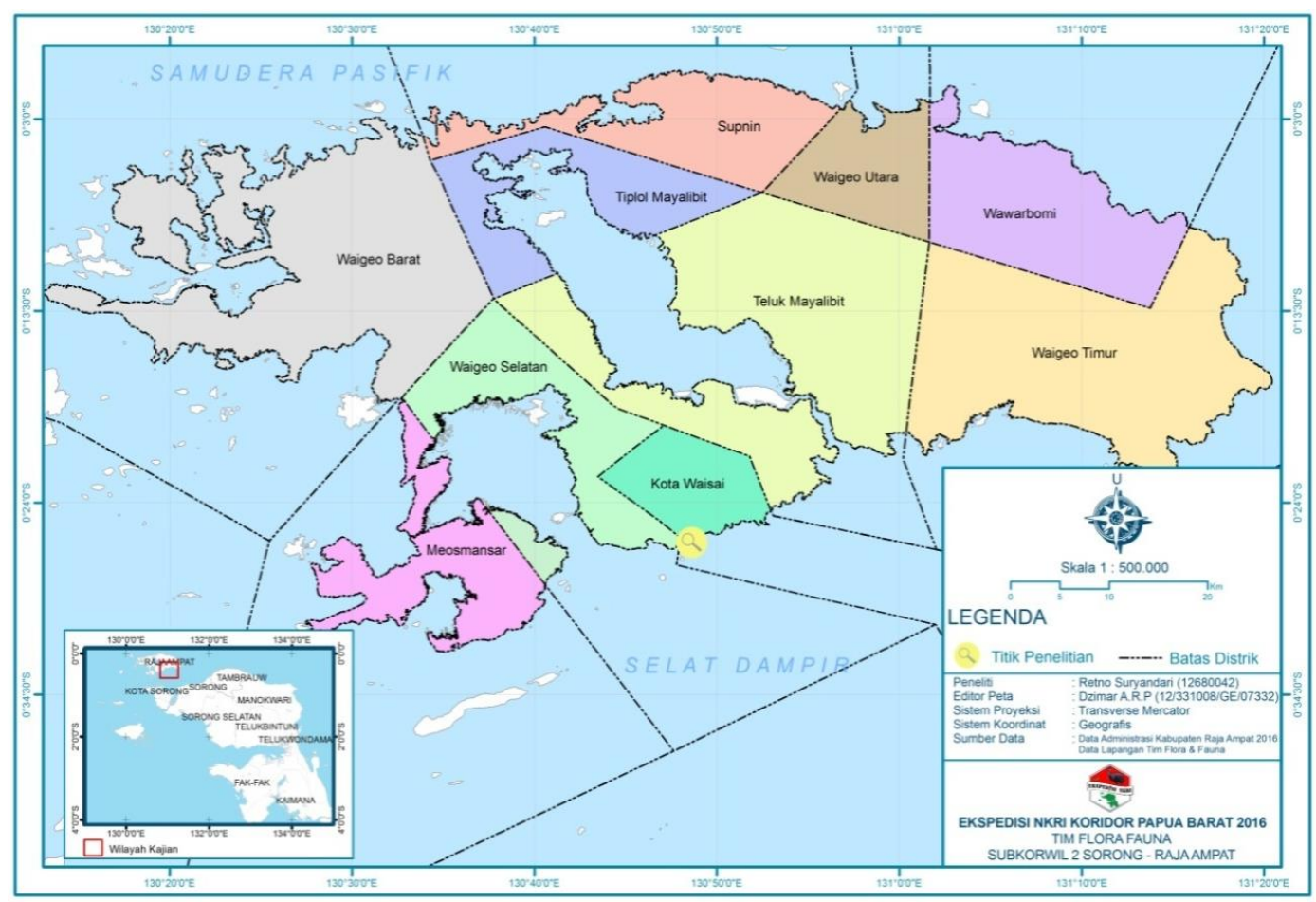

Figure 1. Map of Waigeo Island of Raja Ampat.

The equipment used in this research include waterproof paper, clipboard, pencils 2B, mask snorkel, fins, frame squares size 1x1 meter, GPS (Global Positioning System), a digital camera, underwater camera, identification book, refractometer, $\mathrm{pH}$ meter and thermometer, Materials used in this research are specimens and $10 \%$ formalin.

Sampling vegetation was done using transect quadrat method. Transect line was divided into three stations in one location with the distance of each station is 25 meters. The steps of this research are: 1) Determining the location for line transect stations 1,2 , and 3 with a length of each transect is 50 meters. The distance of each transect lines are installed parallellyand its lengthis 25 meters. Each transect mounted perpendicular to the shoreline, 2) In each transect line is placed a quadrat frame with size $1 \mathrm{~m}$ x $1 \mathrm{~m}$ of 10 quadrat frame with a distance of each quadrat frame is 5 meters. First squares are laid in the area closest to the mainland where macroalgae was found, 3) Calculate all macroalgae in each plot, 4) The amounts found are recorded on paper underwater based on the location of the squares, 5) sampling macroalgae and placed in plastic sample was labeled , 6) samples were found to note the type of the substrates, 7) Took data of environmental parameters such as: the coordinates of Global Positioning System (GPS), the measurement of temperature using a thermometer, measuring salinity of seawater using a refractometer and $\mathrm{pH}$ measurements of water using a pH-meter. 8) Samples were taken washed clean of the substrate and then preserved with formalin $10 \%$ for identification purposes.

\section{Result and Discussion}

Based on the research that has been done, macroalgae were found in Waisai Coast at coordinates S $00^{\circ} 26^{\prime} 12,3$ ", E $130^{\circ} 48^{\prime} 38,7^{\prime \prime}$ are as many as 38 species. Macroalgae that can be identified to species level are 29 species consisting of 17 species of green algae (Chlorophyta), 5 species of red algae (Rhodophyta), 7 species of brown algae (Phaeophyceae), and 9 species unidentified.

\section{Green Macroalgae (Clorophyta)}

Class, Order and Family of green macroalgae that found at Waisai Coast shown in the table 1 below. 
Table 1. Checklist of Green Macroalgae that found at Waisai Coast.

\begin{tabular}{|c|c|c|c|}
\hline Class & Order & Family & Species \\
\hline \multirow[t]{17}{*}{ Ulvophyceae } & Bryopsidales & Caulerpaceae & Caulerpa macra (Weber-van Bosse) Draisma \& Prud'homme \\
\hline & & & Caulerpa racemosa var. macrophysa (Sonder wx Kutzing) W.R.Taylor \\
\hline & & & Caulerpa sertularoides (S. Gmelin) Howe f. brevipes (J. Agardh Svedilus) \\
\hline & & & Caulerpa cupressoides (Vahl) C. Agardh \\
\hline & & Halimedaceae & Halimeda discoidea Decaisne \\
\hline & & & Halimeda Opuntia (Linnaeus) J.V. Lamoroux \\
\hline & & & Halimeda tuna (J. Ellis \& Solander) J.V. Lamoroux \\
\hline & & & Halimeda cylindraceae Decaisne \\
\hline & & & Halimeda macroloba Decaisne \\
\hline & & Udoteaceae & Avrainvillea erecta (Berkeley) A. Gepp \& E.S. Gepp \\
\hline & & Codiaceae & Codium geppiorum O.C.Schmidt \\
\hline & Cladophorales & Valoniaceae & Boergesenia forbesii (Hardvey) Feldmann \\
\hline & & & Valonia ventricosa J. Agardh \\
\hline & & & Dictyosphaeria cavernosa (Forsskål) Børgesen \\
\hline & & Cladophoraceae & Chaetomorpha spiralis Okamura \\
\hline & & Anadyomenaceae & Anadyomene wrightii Harvey ex. J. E. Gray \\
\hline & Dasycladales & Dasycladaceae & Neomeris annulata Dickie \\
\hline
\end{tabular}

\section{Caulerpa macra (Weber-van Bosse) Draisma \& Prud'homme (Fig. 2A)}

Description: Large Caulerpa with long thick stolons, these several decimeters long, 3-5 $\mathrm{mm}$ in width but often over $5 \mathrm{~mm}$. Rhizoidal pillars well developed, arising from stolons at irregular distances, up to $10 \mathrm{~cm}$ long and several $\mathrm{mm}$ in diameter, often with thick terminal clumps of branched rhizoids. Erect assimilators up to $10 \mathrm{~cm}$ in height, with irregularly to regularly placed ramuli arranged distichously or radially and opposite or alternate. Ramuli oviform, pyriform, more rarely claviform, usually with some having a form like the head of a golf club, to $12 \mathrm{~mm}$ long and $6 \mathrm{~mm}$ in width (Belton et al, 2014)

Distribution in Southeast Asia: Indonesia, Java, Philippines (Guiry \& Guiry, 2017).

\section{Caulerpa racemosa var. macrophysa (Kiitzing) Taylor} (Fig. 2B)

Description: Plants large, to $100 \mathrm{~mm}$ tall, erect branches simple or occasionally branched, few and distantly spaced on stout, creeping stolon, branches bearing ramelli expanded into a hemispherical end and arranged irregularly on terete rachis (Menez \& Calumpong, 1982).

Distribution in Southeast Asia: Indonesia, Singapore, Thailand, Vietnam (Guiry \& Guiry, 2017) Philippines (Menez \& Calumpong, 1982).

\section{Caulerpa sertularoides (S. Gmelin) Howe f. brevipes}

\section{(J. Agardh Svedilus) (Fig.2C)}

Description: Bright to dark green in colour, tubular with delicate, branched stolon and erect assimilators, plumose or feathery resembling palm leaves, up to $13 \mathrm{~cm}$ tall, 8$12 \mathrm{~mm}$ broad, rarely branched, branching generally at the base of assimilators, branchlets opposite, incurve above, needle shaped with pointed apices (Jha et al, 2009).

Distribution in Southeast Asia: Indonesia, Philippines, Singapore, Thailand, Vietnam (Guiry \& Guiry, 2017).

\section{Caulerpa cupressoides (Vahl) C. Agardh (Fig. 2D)}

Description: Dark green, the stolon on the macroalga forms a branching with an elongated shape of ramuli and jagged edges (Atmadja et al, 1996).

Distribution in Southeast Asia: Indonesia, Philippines, Singapore, Vietnam (Guiry \& Guiry, 2017).

\section{Halimeda discoidea Decaisne (Fig. 2E)}

Description: Compact tallus growth, dichotomous or trichotomous branching, rough surface segments, squiggly edges, base segments slightly elongated and thicker (Atmadja et al, 1996).

Distribution in Southeast Asia: Indonesia, Myanmar, Philippines, Singapore, Thailand, Vietnam (Guiry \& Guiry, 2017).

\section{Halimeda Opuntia (Linnaeus) J.V. Lamoroux (Fig. 2F)}

Description: Compact tallus growth, bifurcation of crumpled segments spreading and forming new growth. The relatively small segments are round-shaped, rounded-oval, kidney, and wavy. High carbonate contents. Basal segment is not visible. The non-bulbous holdfast consists of filamentous mass (Atmadja et al, 1996).

Distribution in Southeast Asia: Indonesia, Malaysia, Myanmar, Philippines, Singapore, Thailand, Vietnam (Guiry \& Guiry, 2017). 
Halimeda tuna (J. Ellis \& Solander) J.V. Lamoroux (Fig. 2G)

Description: Dark green in colour, generally tufted, moderately calcified and attached by compressed conical holdfast, branching in one plane, dichotomous or trichotomous upper segments, cuneate remiform discoid, 6-13 $\mathrm{mm}$ high, $5-23 \mathrm{~mm}$ broad,medullary filaments entangled, fusing 2-3 together at the nodes, dichotomously branched above the fused filaments (Jhaet al, 1996).

Distribution in Southeast Asia: Indonesia, Malaysia, Philippines, Singapore, Vietnam (Guiry \& Guiry, 2017).

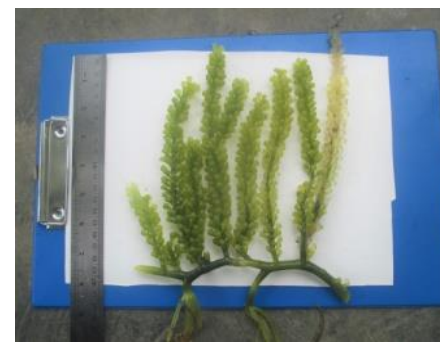

A

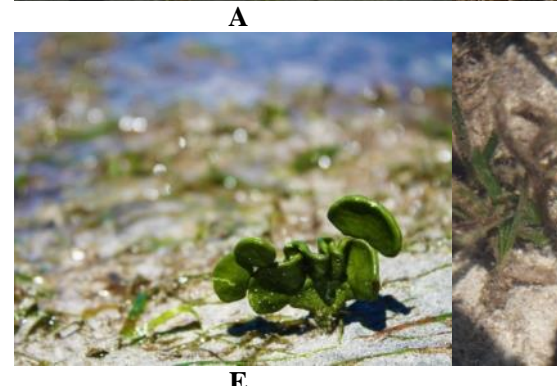

$\mathbf{E}$

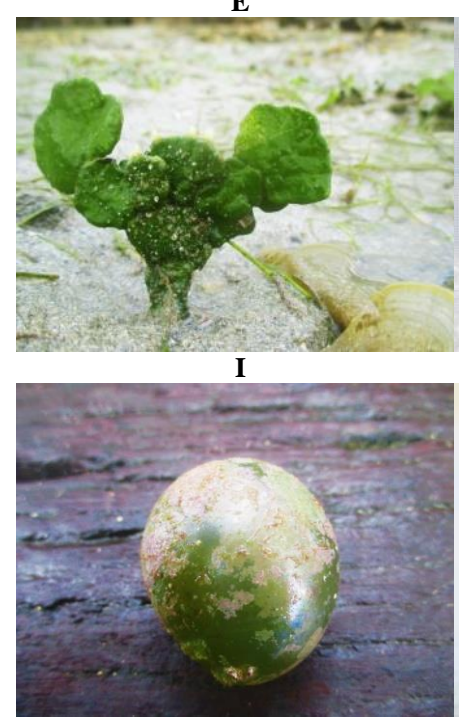

M

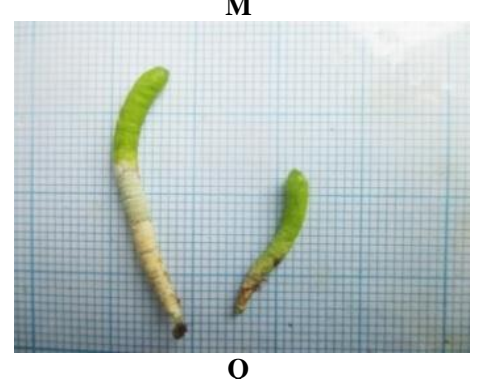

Q

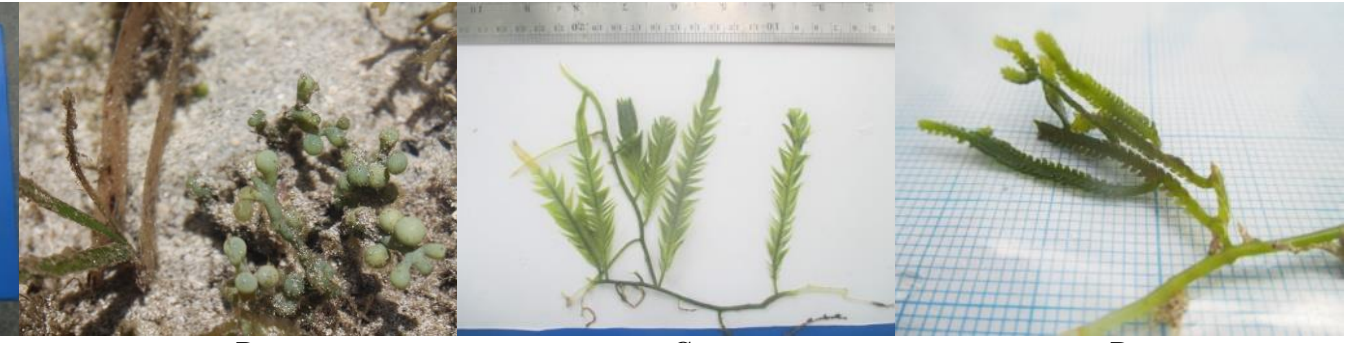

B

$\mathbf{C}$

D

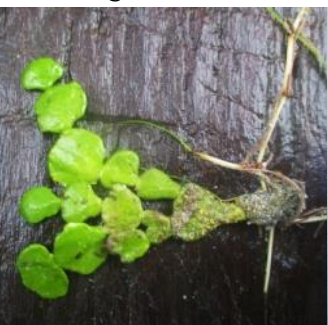

G

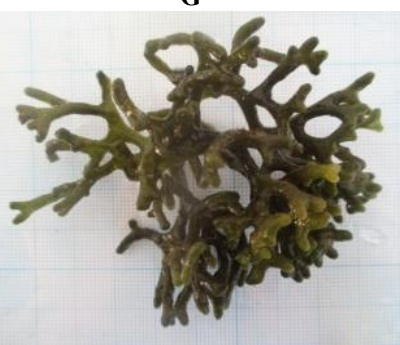

$\mathbf{K}$

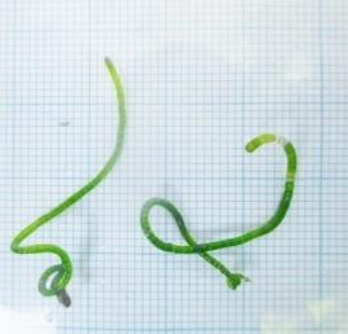

$\mathbf{O}$

Figure 2. Macroalgae of Chlorophyta at Waisai Coast (A. Caulerpa macra (Weber-van Bosse) Draisma \& Prud'homme, B. Caulerpa racemosa var. macrophysa (Sonder wx Kutzing) W.R.Taylor, C. Caulerpa sertularoides (S. Gmelin) Howe f. brevipes (J. Agardh Svedilus), D. Caulerpa cupressoides (Vahl) C. Agardh, E. Halimeda discoidea Decaisne, F. Halimeda Opuntia (Linnaeus) J.V. Lamoroux, G. Halimeda tuna (J. Ellis \& Solander) J.V. Lamoroux, H. Halimeda cylindraceae Decaisne, I. Halimeda macroloba Decaisne, J. Avrainvillea erecta (Berkeley) A. Gepp \& E.S. Gepp, K. Codium geppiorum O.C.Schmidt, L. Boergesenia forbesii (Hardvey) Feldmann, M. Valonia ventricosa J. Agardh, N. Dictyosphaeria cavernosa (Forsskål) Børgesen, O. Chaetomorpha spiralis Okamura, P. Anadyomene wrightii Harvey ex. J. E. Gray, Q. Neomeris annulata Dickie).

\section{Halimeda cylindraceae Decaisne (Fig. 2H)}

Description: Perpendicular tallus growth consists of cylindrical segments or prisms. Main dichotomous branching, tallus growth toward small bud, width segment size $18 \mathrm{~mm}$, length $10 \mathrm{~mm}$. Between the basal segment and the segment sometimes there is a segment bearing as a place for the formation of new segment 
growth or segment basal branching. Holdfast tuber or tuber (Atmadja et al, 1996).

Distribution in Southeast Asia: Indonesia, Philippines, Vietnam (Guiry \& Guiry, 2017).

\section{Halimeda macroloba Decaisne (Fig. 2I)}

Description: Green in colour when not calcified, solitary, erect, 7-12 cm long, branched in one plane giving it a flat appearance, attached by a cylindrical holdfast, upper segments discoid, reniform, rounded, 0.5-1.5 cm high, $1.5-2.0 \mathrm{~cm}$ broad, margins thick entire, branching di- to tri-chotomous above and polychotomous at the basal part, cortex commonly composed of 3-4 layers of utricles, outermost utricles slightly attached when young and separating on decalcification when fertile. It is abundant on dead corals (Jha et al, 2009)

Distribution in Southeast Asia: Indonesia, Malaysia, Myanmar, Philippines, Singapore, Thailand, Vietnam (Guiry \& Guiry, 2017).

\section{Avrainvillea erecta (Berkeley) A. Gepp \& E.S. Gepp} (Fig. 2J)

Description: Dark to dull green in colour, erect, up to 8 $\mathrm{cm}$ tall, attached by elongated, densely interwoven basal mass of rhizoids with apical fan-shaped sessile and filamentous foliar position, foliar portions composed of branched filaments about $4 \mathrm{~cm}$ long and $6 \mathrm{~cm}$ broad, spongy to somewhat hairy. It commonly found in muddy substratum with still waters (Jha et al, 2009).

Distribution Southeast Asia: Indonesia, Malaysia, Myanmar, Philippines, Singapore, Thailand, Vietnam (Guiry \& Guiry, 2017).

\section{Codium geppiorum O.C.Schmidt (Fig. 2K)}

Description: Dark green in colour, procumbent, attached by holdfast, $3-5 \mathrm{~cm}$ tall, thallus sub-dichotomously divided and creeping type, branches cylindrical, divergent and compressed, utricles abovate to pyriform with rounded tips, $330-550 \mu \mathrm{m}$ long and $100-300 \mu \mathrm{m}$ broad with slight flattened apices, gametangia fusiform, pedicellate, $1-2$ born on each fertile utricle. Common in tide pools on sheltered rocks (Jha et al, 2009)

Distribution in Southeast Asia: Indonesia, Malaysia, Myanmar, Philippines, Singapore, Thailand, Vietnam (Guiry \& Guiry, 2017).

\section{Boergesenia forbesii (Hardvey) Feldmann (Fig. 2L)}

Description: Yellowish green in colour, $3-5 \mathrm{~cm}$ tall forming patches on the substratum, vesicles slightly curved, clavate, filled with fluid, club-shaped in younger stage enlarged in he upper part giving grape-like appearance in older stage. basal branched filamentous parts of the thallus septate. Common in intertidal rock pools (Jha et al, 2009).
Distribution in Southeast Asia: Indonesia, Myanmar, Philippines, Singapore, Thailand, Vietnam (Guiry \& Guiry, 2017).

Valonia ventricosa J. Agardh (Fig. 2M)

Description: Dark green colour, single round and unbranched thallus, fluid-filled thallus(Olsen \& J.A., 1988).

Distribution in Southeast Asia: Philippines, Singapore, Vietnam (Guiry \& Guiry, 2017). Indonesia (Sukiman et al, 2014).

\section{Dictyosphaeria cavernosa (Forsskål) Børgesen (Fig.} 2N)

Description: Dark green, round hollow rounded with harsh spheres, stiff and slightly thick (Atmadja et al, 1996).

Distribution in Southeast Asia: Indonesia, Malaysia, Myanmar, Philippines, Singapore, Thailand, Vietnam (Guiry \& Guiry, 2017)

\section{Chaetomorpha spiralis Okamura (Fig. 20)}

Description: Plant bluish green in colour, up to $5 \mathrm{~cm}$ long, rigid, spirally coiled, attached by rhizoidal basal cells with simple branched short and blunt rhizoids, cells 400-600 $\mu \mathrm{m}$ in diameter and 2-3 times longer than broad, moniliform or cylindrical in shape (Jha et al, 2009)

Distribution in Southeast Asia: Indonesia, Malaysia, Philippines, Singapore, Thailand, Vietnam (Guiry \& Guiry, 2017).

Anadyomene wrightii Harvey ex. J. E. Gray (Fig. 2P) Description: Light green coloured, no stipe, blade shaped like a corrugated fan with serrated blade edge, on a blade that looks like a leaf-like loop (Anonymous, 2004).

Distribution in Southeast Asia: Indonesia, Philippines, Singapore, Vietnam (Guiry \& Guiry, 2017).

\section{Neomeris annulata Dickie (Fig. 2Q)}

Description: Light green colour, thallus cylindrical and unbranched, calcified basal part, the apical portion consists of green fibers (Jha et al, 2009).

Distribution Southeast Asia: Indonesia, Myanmar, Philippines, Singapore, Thailand, Vietnam (Guiry \& Guiry, 2017).

\section{Red Macroalgae (Rodhophyta)}

Class, Order and Family of redmacroalgae that found at Waisai Coast shown in the table 2 below. 
Table 2. Checklist of Red Macroalgae that found at Waisai Coast.

\begin{tabular}{llll}
\hline Class & Order & Family & Species \\
\hline Florideophyceae & Ceramiales & Rhodomelaceae & Acanthophora spicifera (M. Vahl) B $\emptyset$ rgesen \\
& & Laurencia papilosa (C. Agardh) Greville \\
& & Gracilaria salicornia (C. Agardh) E.Y. Dawson \\
& Corallinales & Corallinaceae & Amphiora fragilissima (Linnaeus) J.V. Lamoroux \\
& Gigartinales & Cyatocloniaceae & Hypnea pannosa J. Agardh
\end{tabular}

Acanthophora spicifera (M. Vahl) Børgesen (Fig. 3A)

Description: Yellowish brown colour, erect plants, to 40 $\mathrm{cm}$ tall, with solid cylindrical branches, 2 - $3 \mathrm{~mm}$ wide, branched either sparingly to repeatedly. Main branches have short, determinate branches, irregularly shaped and spinose, with spines numerous and radially arranged. There are no spines on main axes. The plant grows from a large, irregularly shaped holdfast. (Anonymous, 2001).

Distribution in Southeast Asia: Indonesia, Malaysia, Myanmar, Philippines, Singapore, Thailand, Vietnam (Guiry \& Guiry, 2017).

\section{Laurencia papilosa (C. Agardh) Greville (Fig. 3B)}

Description: Plants about 5-16 tall, growing in dense clusters. The lower parts of the plants are smooth, but toward the ends, the branches are sparsely crowded with short, truncate to tuberculate branchlets. Plants olive green to greenish purple in colour, consistency somewhat cartilaginous (Kluijvver, Gijswijt, Leon, and Cunda, 2012)

Distribution in Southeast Asia: Indonesia, Philippines, Vietnam (Guiry \& Guiry, 2017).

\section{Gracilaria salicornia (C. Agardh) E.Y. Dawson (Fig. 3C)}

Description: Brownish to yellowish red in colour, up to $16 \mathrm{~cm}$ in height, attached by small discs, thallus bushy with irregularly branched, cylindrical axes, lower branches cylindrical, not attenuated at the base, upper branches attenuated below, elongate clavate, swollen at the apex and showing apical depressions, one or two branchlets arising from the depressions, cortex 1-2

layered, medulla with large central cells, cystocarps scattered all over the thallus, rostrate (Jha, 2009).

Distribution in Southeast Asia: Indonesia, Malaysia, Myanmar, Philippines, Singapore, Thailand, Vietnam (Guiry \& Guiry, 2017).

\section{Amphiora fragilissima (Linnaeus) J.V. Lamoroux} (Fig. 3D)

Description: Purple red in colour, up to $3 \mathrm{~cm}$ tall, calcified, erect, fragile, regularly dichotomously or trichotomously branched, sometimes with adventitious branches, apices obtuse, segments or intergenicula cylindrical or slightly compressed, several times longer than broad, sometimes with pad-like swellings at the tip, conceptacles lateral, hemispherical, prominent (Jhaet al, 1996).

Distribution in Southeast Asia: Indonesia, Myanmar, Philippines, Singapore, Thailand, Vietnam (Guiry \& Guiry, 2017).

\section{Hypnea pannosa J. Agardh (Fig. 3E)}

Description: $H$. pannosa has densely entangled plants and tetrasporangial sori usually growing on one side of branchlets, than gradually completely surrounding the branchlets. This macroalgae are most commonly found growing abundantly on stable rocks of middle to lower intertidal zones, but sometimes they can be found growing in tide pools, branchlets are thick almost all the way to the apex, and the branch tips are often divaricate (Chiang, 1990).

Distribution in Southeast Asia: Indonesia, Myanmar, Philippines, Singapore, Thailand, Vietnam (Guiry \& Guiry, 2017).

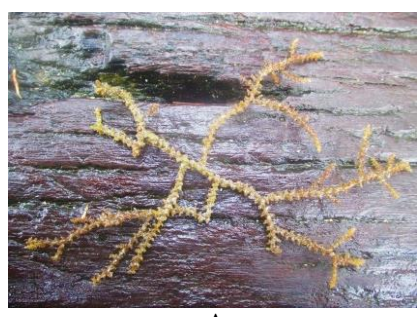

A

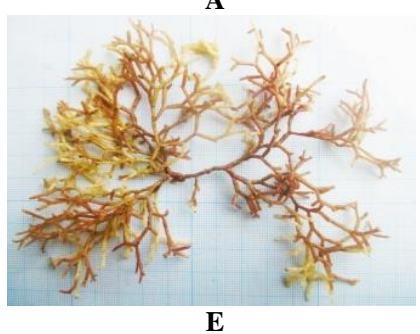

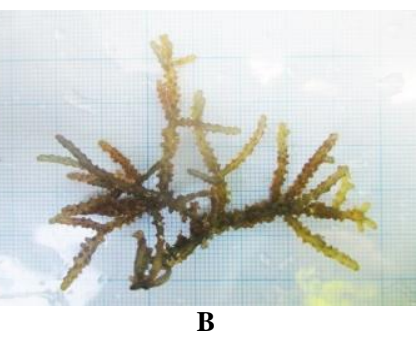

B

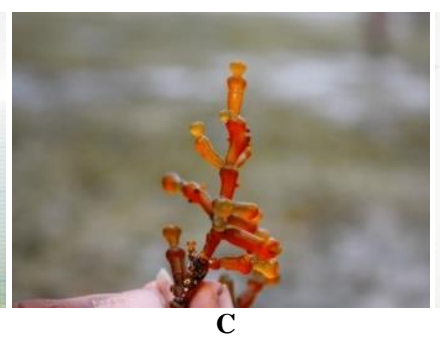

C

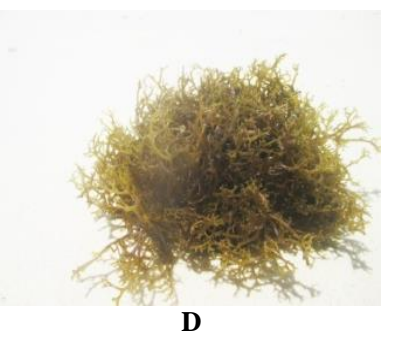

Figure 3. Macroalgae of Rhodophyta at Waisai Coast (A. Acanthophora spicifera (M. Vahl) Børgesen, B. Caulerpa Laurencia papilosa (C. Agardh) Greville, C. Gracilaria salicornia (C. Agardh) E.Y. Dawson, D. Gracilaria salicornia (C. Agardh) E.Y. Dawson, D. Amphiora fragilissima (Linnaeus) J.V. Lamoroux, E. Hypnea pannosa J. Agardh.). 


\section{Brown Macroalgae (Phaeophyceae)}

Class, Order and Family of brown macroalgae that found at Waisai Coast shown in the table 3 below.

Table 3. Checklist of Brown Macroalgae that found at Waisai Coast.

\begin{tabular}{|c|c|c|c|}
\hline Class & Order & Family & Species \\
\hline \multirow[t]{7}{*}{ Phaeophyceae } & Fucales & Sargassaceae & Hormophysa cuneiformis (J.F. Gmelin) P.C. Silva \\
\hline & & & Sargassum aquifolium (Turner) C. Agardh \\
\hline & & & Sargassum polycystum C. Agardh \\
\hline & & & Turbinaria ornata (Turner) J. Agardh \\
\hline & Dictyotales & Dictyotaceae & Padina australis Hauck \\
\hline & & & Canistrocarpus cervicornis (Kutzing) De Paula \& De Clerck \\
\hline & Ectocarpales & Scytosiphonaceae & Hydroclathrus clatratus (C. Agardh) M. Howe \\
\hline
\end{tabular}

Hormophysa cuneiformis (J.F. Gmelin) P.C. Silva (Fig. 4A)

Description: Dark brown in colour, $30 \mathrm{~cm}$ in height or more, sparsely branched, pseudo-dichotomously branched, branches articulated, triangular articulation narrow at the base, 3-5 $\mathrm{mm}$ broad, margins dentate, vesicles ellipsoid or oblong, embedded in the middle of swollen wings, solitary (Jha et al, 2009). Irregularly branched thallus, blade-shaped blade-like wings with three sides and a serrated edge, holdfast filament-shaped filaments (Tsuda, 2004).

Distribution in Southeast Asia: Indonesia, Malaysia, Myanmar, Philippines, Singapore, Thailand, Vietnam (Guiry \& Guiry, 2017).

\section{Sargassum aquifolium (Turner) C. Agardh (Fig. 4B)}

Description: Thallus medium brown, $10-45 \mathrm{~cm}$ tall, with a discoid-crustose holdfast 7-11 mm wide. Primary axes terete, smooth, 3-4 mm long, 1.25-2.00 mm diameter. Primary branches smooth to wrinkled, compressed, with sharp edges, 2-4 mm wide. Primary laterals alternate, linear lanceolate to ovate-elongate, 13-30 mm long, 5-11 $\mathrm{mm}$ wide, margins undulate to deeply dentate, apices obtuse, base subsymmetrical, cuneate, arising directly from the stem and lacking a distinct stalk,margins vanishing $80 \%$ of the way to the apex (Huisman \& Parker, 2016).

Distribution in Southeast Asia: Indonesia (Guiry \& Guiry, 2017).

\section{Sargassum polycystum C. Agardh (Fig. 4C)}

Description: Thallus yellowish brown in colour, attached with discoid holdfast, main axis cylindrical and rough due to the presence of numerous outgrowth, supporting alternately arranged branches bearing blade and vesicles. In young thalli, blades are longer and broader measuring 13-42 $\mathrm{mm}$ long including the stipe and $2.5-11.5 \mathrm{~mm}$ wide, blades are generally oblong slightly tapered, retuse (slightly rounded) or emarginated at the tip finally serrated throughout the margin, mature thalli fewer leaves smaller. Cryptostomates are scattered on the surface of the blade (Mattio \& Payri, 2009). This macroalgae has secondary holdfast that is transformed from the stolon and heavily muricate on main branch (Noiraksa, Ajisaka, \& Kaewsuralikhil, 2006).

Distribution in Southeast Asia: Indonesia, Philippines, Singapore (Guiry \& Guiry, 2017).

\section{Turbinaria ornata (Turner) J. Agardh (Fig. 4D)}

Description: Dark brown in colour, up to $50 \mathrm{~cm}$ tall, bushy, axes arising from dichotomously branched holdfast, main axes erect and cylindrical and irregularly branched, leaves closely arranged, turbinate to obconical, coarse, $0.5-1.5 \mathrm{~cm}$ long $10-15 \mathrm{~mm}$ broad at the distal ends, distal ends of the leaves triangular, subconcave with double row of spines on the surface with terete stalks, vesicles immerged in the leaves, receptacles racemose, arising on the stalks of the upper leaves(Jha et al, 2009).

Distribution in Southeast Asia: Indonesia, Malaysia, Myanmar, Philippines, Singapore, Thailand, Vietnam (Guiry \& Guiry, 2017).

\section{Padina australis Hauck (Fig. 4E)}

Description: Brownish yellow, fan-shaped thallus, texture like a membrane, there is a concentric spike that follows the shape of the thallus, calcareous surface part, rhizoid holdfast (Atmadja et al, 1996).

Distribution in Southeast Asia: Indonesia, Malaysia, Myanmar, Philippines, Singapore, Thailand, Vietnam (Guiry \& Guiry, 2017).

\section{Canistrocarpus cervicornis (Kutzing) De Paula \& De Clerck (Fig. 4F)}

Description: Growth from ascending, resupinate, attached to tha substrate by broad, erect part more slender and supple, epiphytic specimens generally lack a conspicuous basal part, Color yellow to dark brown, dry specimens apical part pale brown, basal part turn a bit darker. Branching isotomous dichotomous up to the middle parts typically cervicorn, recurved branches often with cervicorn, branching angle (30) 60-90 (120). Margins and surface margins smooth and sinoidally curved (Darakrai, 2012). 
Distribution in Southeast Asia: Indonesia, Malaysia, Myanmar, Philippines, Singapore, Vietnam (Guiry \& Guiry, 2017), Thailand (Darakrai, 2012).

\section{Hydroclathrus clatratus (C. Agardh) M. Howe (Fig. 4G)}

Description: Yellowish to dark brown in colour, up to $12 \mathrm{~cm}$ long, 4-8 cm broad, vesicular or irregularly ovate, un-perforated when young, hollow and perforated as net like structures when mature, perforations variable in size, rounded, margins around perforations involute, thallus composed of an epidermal layer and a zone of colourless cells bellow the epidermis, plurolocular sori scattered all over the surface of the thallus, hairs grouped in shallow depression. (Jha et al, 2009).

Distribution in Southeast Asia: Indonesia, Malaysia, Myanmar, Philippines, Singapore, Thailand, Vietnam (Guiry \& Guiry, 2017).

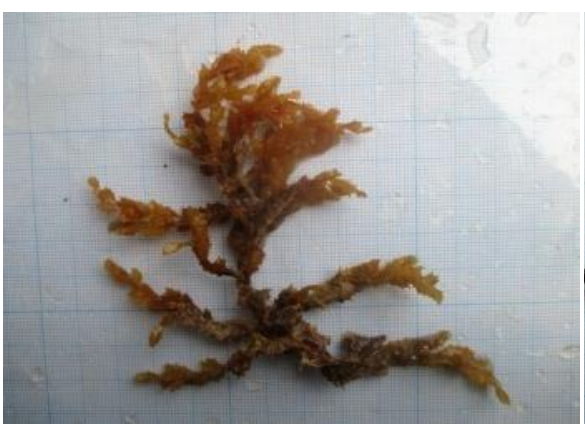

A

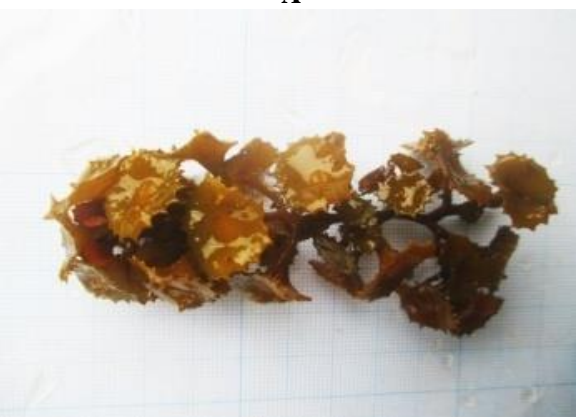

D

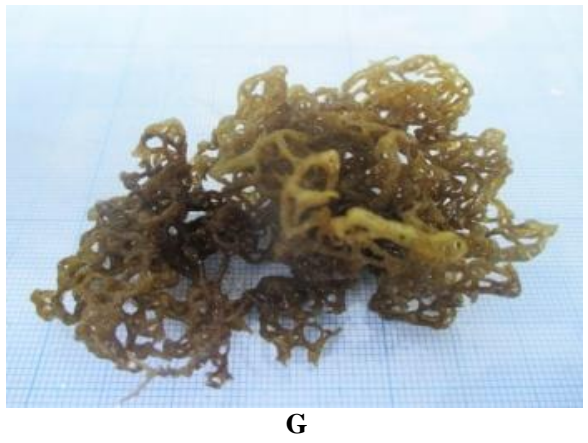

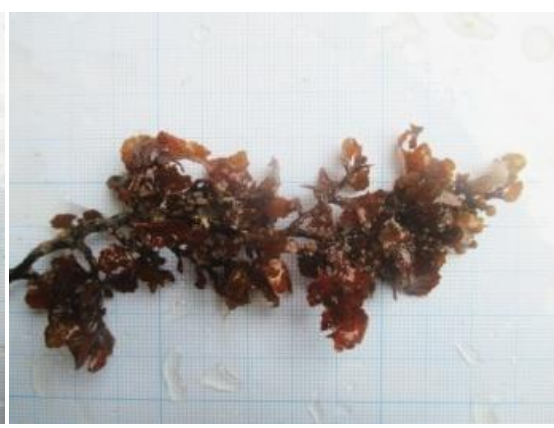

B

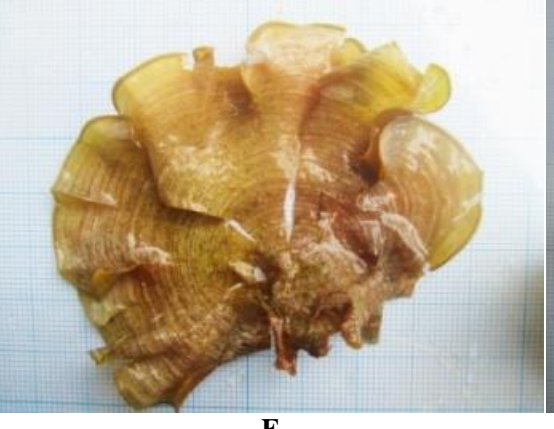

$\mathbf{E}$

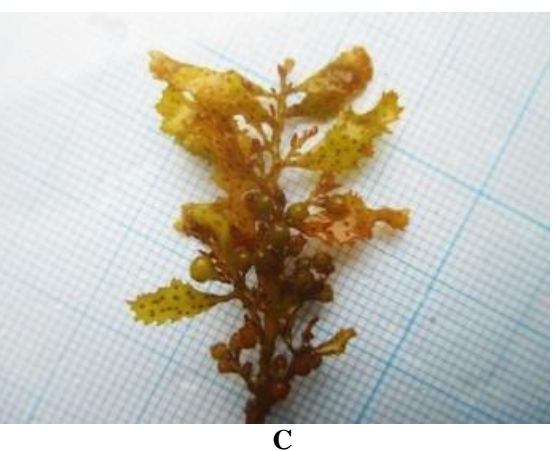

C

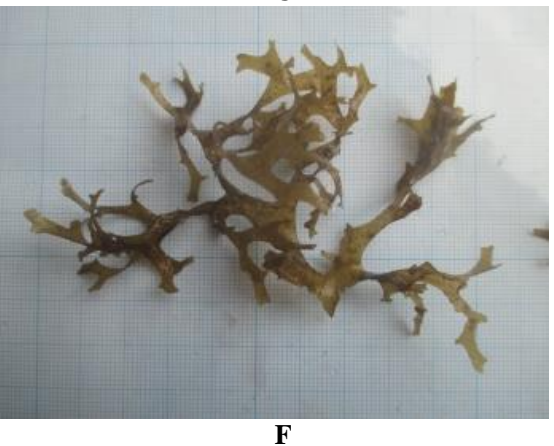

Figure 4. Macroalgae of Phaeophyceae at Waisai Coast (A. Hormophysa cuneiformis (J.F Gmelin) P.C. Silva,B. Sargassum aquifolium (Turner) C. Agardh, C. Sargassum polycystum C. Agardh, D. Turbinaria ornata (Turner) J. Agardh, E. Padina australis Hauck, F. Canistrocarpus cervicornis (Kutzing) De Paula \& De Clerck, G. Hydroclathrus clatratus (C. Agardh) M. Howe.

There are nine specimens of macroalgae that can't be identified to species level, namely: Sp. 3. Brown colour, Brown colour, flat stipe with irregular blade branches, thin blade and branches, penumatocyst found on the base of the blade (Figure 5A). Eucheuma sp. Dark green in colour, irregular branching, cylindrical blade tip of each branch and the main branch off two or three (Figure 5B). Gracilaria sp. 1.Colour pale brown, small thallus with bumps smooth surface (Figure 5C). Gracilaria sp. 2. The green colour, thin cylinder-shaped thallus with sparse branching, the tip of the needleshaped thallus (Figure 5D). Gracilaria sp. 3. Colour brown, thallus like a needle with a larger size, thick and rigid, irregular branching (Figure 5E). Sp. 1. The colour brown, thallus branching from the base about 5 branches with each branch are spina-bifida short (Figure 5F). Sp. 2. Dark green colour, thick thallus and looked porous, spherical and elongated like a tool at the thallus filled with fluid (Figure 5G). Sp. 3. The colour is yellowbrown, primary branches cylindical, opposite branches arrangement, the blade is lanceolate and the margin is jagged (Figure 5H). Sp. 4. The colour is dark brown, primary branches cylindical, opposite branches arrangement, the blade is linear like spinose with the apex rounded (Figure 5. G, I). 


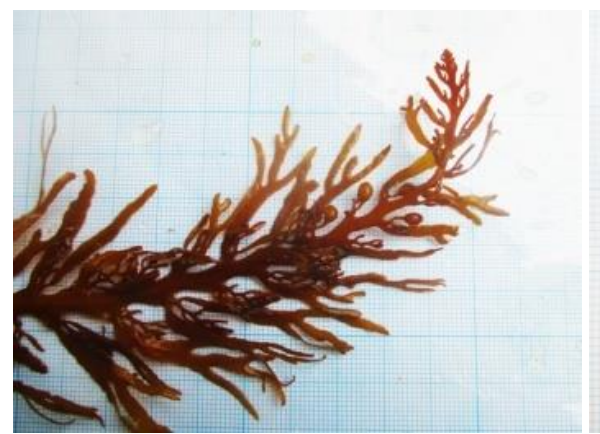

$\mathbf{A}$

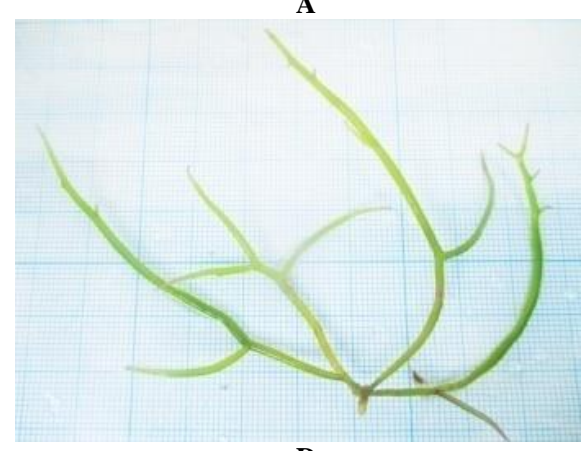

D

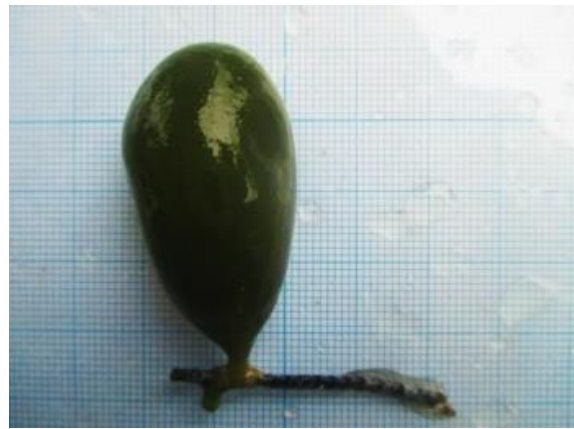

$\mathbf{G}$

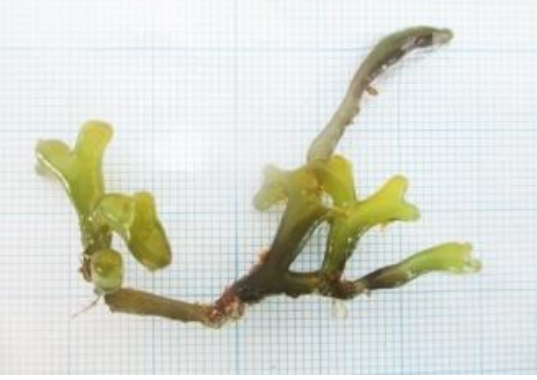

B

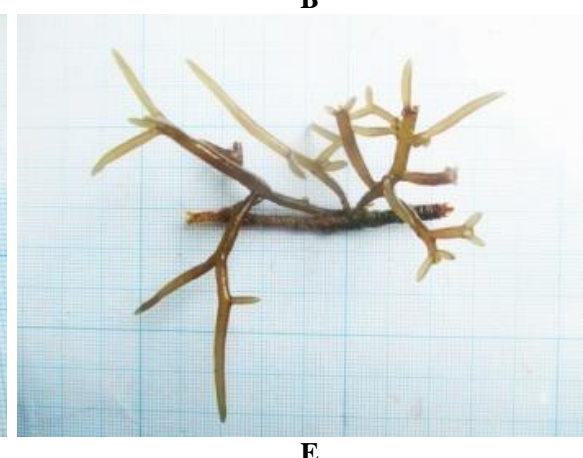

$\mathbf{E}$

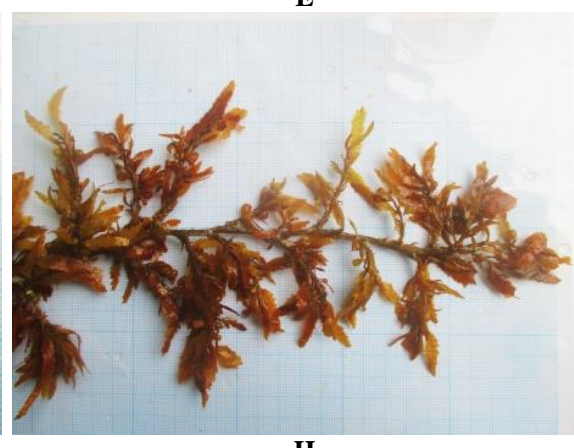

$\mathbf{H}$

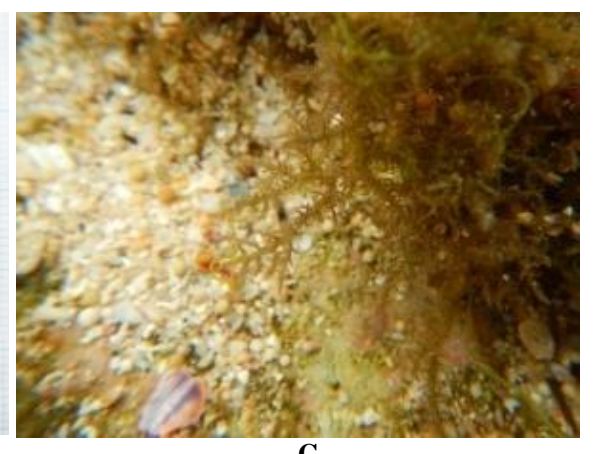

C

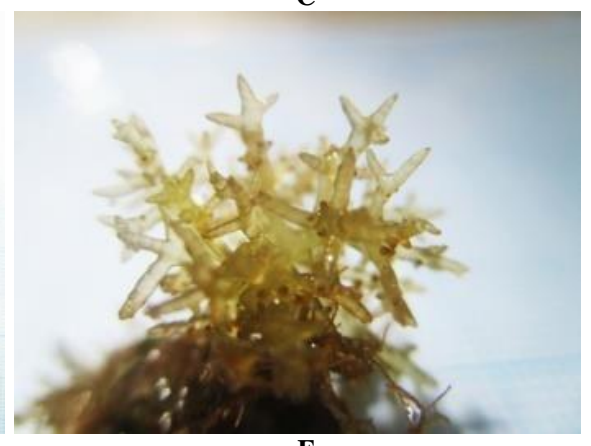

$\mathbf{F}$

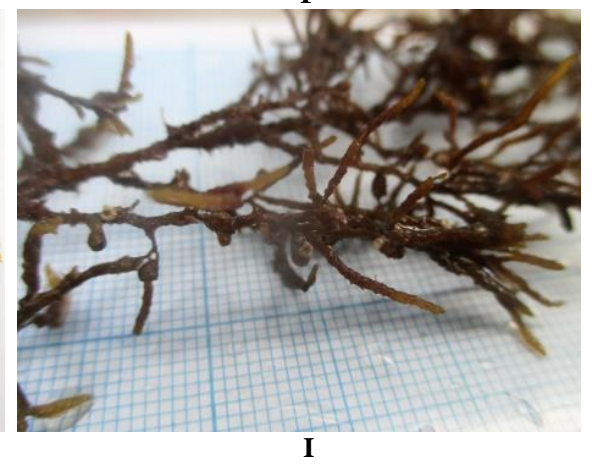

Figure 5. Macroalgae that cannot be identified to species level at Waisai Coast (A.Sp. 3, B. Eucheuma sp., C.Gracilaria sp. 1, D.Gracilaria sp. 2, E.Gracilaria sp. 3, F.Sp. 1, G.Sp. 2, H. Sp. 3, I. Sp. 4.

Table 4. Environmental parameters of Waisai Coast.

\begin{tabular}{lllll}
\hline Environmental parameters & Site $\mathbf{1}$ & Site 2 & Site 3 & Average \\
\hline Salinity & $32 \%$ o & $30 \% 0$ & $31 \% 0$ & $31 \%$ \\
Temperature & $29,4{ }^{\circ} \mathrm{C}$ & $29,7{ }^{\circ} \mathrm{C}$ & $30,7{ }^{\circ} \mathrm{C}$ & $29.9{ }^{\circ} \mathrm{C}$ \\
pH & 8,05 & 8,22 & 8,23 & 8.17 \\
\hline
\end{tabular}

Twenty nine identified macroalgae species have been found in previous studies in Southeast Asia. Southeast Asia region where the species are found, among others Indonesia, Malaysia, Myanmar, Philippines, Singapore, Thailand, and Vietnam.

Species that can be found in the seven countries of Southeast Asia region are Halimeda Opuntia (Linnaeus) J.V. Lamoroux, Halimeda macroloba Decaisne, Avrainvillea erecta (Berkeley) A. Gepp \& E.S. Gepp, Codium geppiorum O.C. Schmidt, Dictyosphaeria cavernosa (Forsskål) Børgesen, Acanthophora spicifera (M. Vahl) Børgesen, Gracilaria salicornia (C. Agardh) E.Y. Dawson, Hormophysa cuneiformis (J.F. Gmelin) P.C. Silva, Turbinaria ornata (Turner) J. Agardh, Padina australis Hauck, Canistrocarpus cervicornis
(Kutzing) De Paula \& De Clerck Hydroclathrus clatratus (C. Agardh) M. Howe.

Halimeda cylindraceae Decaisne, Laurencia papilosa (C. Agardh) Greville found only in Indonesia, Philippines, and Vietnam. As for species found only in Indonesia, Philippines, and Singapore is Sargassum polycystum C. Agardh. The only species found in Indonesia is Sargassum aquifolium (Turner) C. Agardh (Guiry \& Guiry, 2017).

Halimeda cylindraceae is a species of the genus Halimeda. Halimeda is a genus that has a characteristic thallus form of segments that contain calcium $\mathrm{CaCO}_{3}$. The content of the lime produced from the process of calcification is an important role for the environment. When individuals macroalgae of the genus Halimeda is 
dead, then the content of calcium will be major contributors to the formation of coral reefs (Wizemann \& Meyer, 2014). Genus Halimeda addition, some other species also contribute to the environment. Laurencia papilosa which are still found in three countries of Asia also have a role for the environment. Macroalgae have been tested have the ability to eliminate waste water colour stain on the textile industry (El Maghraby, 2013).

The methanol extract of $S$. aquifolium has the greatest free radical inhibiting activity and the antioxidant activity index is 0.54 . Based on the rules of the antioxidant activity index, the methanol extract of $S$. aquifolium is classified as moderate antioxidant activity (Muhamad, 2013)

This research shows the water temperature at the location of the study had an average of $29.9^{\circ} \mathrm{C}$, salinity $31 \%$ and an average $\mathrm{pH}$ of 8.23 . Basically every type of macroalgae have standardized optimum temperature for growth vary. According to Amalia (2013), the optimum temperature for growth of particular species of macroalgae Gracillaria verrucosa ranged $22-27^{\circ} \mathrm{C}$ but at a temperature of $31 \mathrm{C}$ can still grow although not with good quality. According Raiker (2001) in the Chung (2007) states that the optimal salinity for the growth of macroalgae that are at normal salinity of seawater is 35 psu. As for $\mathrm{pH}$, according Marianingsih et al (2013) seaweed can grow continuously at $\mathrm{pH} 7-8$. Based on environmental factors shows that the temperature and salinity of the water obtained in the studies are not optimal location to support the growth of algae. While the $\mathrm{pH}$ found in the study site can be classified include the appropriate $\mathrm{pH}$ for growth of macroalgae.

\section{Conclusion}

Based on the research, macroalgae found in Waisai Coast Raja Ampat are green algae, red algae and brown algae. Green algae found and identified are Caulerpa macra (Weber-van Bosse) Draisma \& Prud'homme, Caulerpa racemosa var. macrophysa (Sonder wx Kutzing) W.R.Taylor, Caulerpa sertularoides (S. Gmelin) Howe f. brevipes (J. Agardh Svedilus), Caulerpa cupressoides (Vahl) C. Agardh, Halimeda discoidea Decaisne, Halimeda Opuntia (Linnaeus) J.V. Lamoroux, Halimeda tuna (J. Ellis \& Solander) J.V. Lamoroux, Halimeda cylindraceae Decaisne, Halimeda macroloba Decaisne, Avrainvillea erecta (Berkeley) A. Gepp \& E.S. Gepp, Codium geppiorum O.C.Schmidt, Boergesenia forbesii (Hardvey) Feldmann, Valonia ventricosa J. Agardh, Dictyosphaeria cavernosa (Forsskål) Børgesen, Chaetomorpha spiralisOkamura, Anadyomene wrightii Harvey ex. J. E. Gray, Neomeris annulata Dickie. Red algae species found and successfully identified areAcanthophora spicifera (M. Vahl) Børgesen, Laurencia papilosa (C. Agardh) Greville, Gracilaria salicornia (C. Agardh) E.Y. Dawson, Amphiora fragilissima (Linnaeus) J.V. Lamoroux, Hypnea pannosa J. Agardh. Brown algae species found and identified are Hormophysa cuneiformis (J.F. Gmelin) P.C. Silva, Sargassum aquifolium (Turner) C. Agardh, Sargassum polycystum C. Agardh, Turbinaria ornata (Turner) J. Agardh, Padina australis Hauck, Canistrocarpus cervicornis (Kutzing) De Paula \& De Clerck Hydroclathrus clatratus (C. Agardh ) M. Howe. The only species found in Indonesia is Sargassum aquifolium.

\section{References}

Anonim. 2001. Algae: Invasive Alien. www.hawaii.edu. retrieved at 22 February 2017

Anonim. 2004. Seaweed of Africa. www.seaweedafrica.org. retrieved at 20 February 2017

Atmadja, W., Kadi, A., Sulistijo, \& R, S. (1996). Pengenalan Jenis-Jenis Rumput Laut Indonesia. Jakarta: LIPI.

Castro, P., \& Huber, M. E. (2010). Marine Biology. New York: McGrawHill.

Chiang, Y. (1990). Species of Hypnea Lamoroux (Gigartinales, Rhodophyta) from Taiwan. Oxford: National Sea Grant Library.

Darakrai, A. (2012). Diversity, Species Composition and Habitat of the Genus Dictyota J.V. Lamour. and Canistrocarpus De Paula \& De Clerck in the Peninsular Thailand. Thesis. Prince of Songkla University

El Maghraby, D. M. (2013). Evaluation of Non-viable Biomass of Laurencia Papilosa for Decolorization of Dye Waste Water. African Journal of Biotechnology, 12, 2215-2223.

Huisman, J., \& Parker. (2016). Florabase. www.florabase.dpaw.wa.gov.au. Accessed March 14 ${ }^{\text {th }}, 2017$

Jha, B., Reddy C.R., T. M., \& M.U, R. (2009). Seaweeds of India. New York: Springer.

Jha, B., Reddy, C., Thakur, M. C., \& Rao, M. U. (2009). Seaweeds of India. London: Springer.

Kluijvver, M., Gijswijt, G., Leon, R. D., \& Cunda, I. (2012). Interactive Guide to Carribean Diving. www.speciesidentification.org.

Lasabuda, R. (2013). Pembangunan Wilayah Pesisir Dan Lautan Dalam Perspektif Negara Kepulauan Republik Indonesia. Jurnal Ilmiah Platax , 92-101.

Mambrisaw, A., Wurlianty, B., Liuw, F., \& Hamel, S. (2006). Atlas sumber Daya Pesisir Kabupaten Raja Ampat. Raja Ampat: Conservation International Indonesia.

Mattio, \& Payri. (2009). Macoi : University of Coimbra. Retrieved April 3, 2017, from Portuguese Seaweeds Website: http://macoi.ci.uc.ptf

Noiraksa, T., Ajisaka, T., \& Kaewsuralikhil, C. (2006). Species Sargassum in the East Coast of The Gulf of Thailand. Science Asia, 32, 99-106.

Olsen, J., \& J.A., W. (1988). Ventricara (SiphonocladalesCladophorales Complex, Chlorophyta). a New Genus for Valonia ventricosa. Department of Botany, 56, 103-108.

Solihin, A., Batungbacal, E., \& Nasution, A. M. (2013). Laut Indonesia Dalam Krisis. Jakarta: Greenpeace.

Sukiman, Muspiah, A., Astuti, S. P., Ahyadi, H., \& Aryanti, E. (2014). Keanekaragaman dan Distribusi Spesies Makroalga di Wilayah Sekotong Lombok Barat. Jurnal Penelitian UNRAM, 18, 71-81.

Tsuda, R. (2004). Hormophysa cuneiformis (Phaeophyta: Fucales) in Micronesia. Pasific Sciennce, 58, 23-26.

Wizemann, A., \& Meyer, F. W. (2014). A New Model for The Calcification of The Calcification of The Green Macro-Alga Halimeda opuntia (Lamoroux). Berlin: Springer.

Yagci, M., \& Turna, I. (2002). A New Record for The ALgal Floral of Turkey: Chaetomorpha crassa (C. Ag.) Kutz. (Cladophoraceae, Chlorophyceae). Turk J Bot, 26, 171-174. 